Apuntes Universitarios, 2020: 10(4), octubre-diciembre

ISSN: 2304-0335 DOI:https://doi.org/10.17162/au.v10i4.507

\title{
Proporcionar un modelo de gestión de recursos humanos basado en la gestión del conocimiento en las organizaciones ejecutivas de Sari
}

\section{Providing a Human Resource Management Model based on Knowledge Management in Sari Executive Organizations}

\author{
Mahsa Shah Moradi ${ }^{1 a}$, Sanjar Salajegheh ${ }^{2}$, Aflatoon Amiri ${ }^{3}$, Masoud Pourkiani ${ }^{4}$ y \\ Ayob Sheykhi ${ }^{5}$ \\ Islamic Azad University, Kerman, Iran ${ }^{1234}$ \\ Shahid Bahonar University of Kerman, Iran ${ }^{5}$ \\ ID Orcid ID: https://orcid.org/0000-0001-5507-7417 \\ Orcid ID: https://orcid.org/0000-0002-3412-67312 \\ Orcid ID: https://orcid.org/0000-0003-2413-4313 3 \\ Orcid ID: https://orcid.org/0000-0002-5370-3768 \\ Orcid ID: https://orcid.org/0000-0002-3731-6012
}

Recibido: 12 de febrero de 2020

Aceptado: 12 de julio de 2020

\begin{abstract}
Resumen
Las organizaciones ejecutivas necesitan diseñar procesos estratégicos a fin de utilizar recursos humanos efectivos para una mayor productividad. Entonces, la presente investigación tuvo como objetivo proporcionar un modelo de gestión de recursos humanos basado en la gestión del conocimiento en las organizaciones ejecutivas de Sari, Irán. Esta investigación se aplica en términos de propósito y su método es la investigación por encuesta. La naturaleza de este estudio es descriptiva con el tipo de correlación. La población estadística incluye: 1) 15 expertos familiarizados con el campo de la gestión de recursos humanos que fueron seleccionados mediante el método selectivo; 2) empleados que trabajan en las organizaciones ejecutivas de Sari (29.697 personas) que, según la fórmula de Cochran, se seleccionaron 400 personas por muestreo aleatorio por conglomerados método. La recopilación de datos se realizó mediante un cuestionario de investigación de gestión de recursos humanos con 54 preguntas y gestión del conocimiento con 24 preguntas. La CVR se calculó como 0.97 .4 y 0.95 .1 , respectivamente, y fue aceptable. El coeficiente alfa de Cronbach también se estimó por encima de 0,7, lo que confirma la fiabilidad del instrumento. En el análisis de los datos, se utilizaron exámenes de ruta y modelos de ecuaciones estructurales utilizando el software Lisrel. Basado en el resultado, la fuerza de la relación entre las variables de gestión de recursos humanos y la gestión del conocimiento se calculó en 0.48 , lo que mostró que la correlación es fuerte y deseable. El estadístico t (4.99) también fue mayor que el valor crítico de t al nivel de error del 5\%, es decir, 1.96, lo que indica que la correlación fue significativa. En conclusión, se puede decir que la gestión de recursos humanos y la gestión del conocimiento como dos componentes coordinadores desempeñan un papel determinante en la competitividad de la organización entre sí, y las organizaciones que prestan atención a estos componentes importantes definitivamente lograrán su desarrollo y excelencia deseados.
\end{abstract}


Palabras clave: Gestión de Recursos Humanos, Gestión del Conocimiento, Organizaciones Ejecutivas, Sari, Irán.

\begin{abstract}
Executive organizations need to design strategic processes in order to use effective human resources for increased productivity. So, this research aimed to provide a human resource management model based on knowledge management in executive organizations in Sari, Iran. This research is applied in terms of purpose and its method is survey research. The nature of this study is descriptive with the type of correlation. The statistical population includes: 1) 15 experts familiar with the field of human resource management who were selected using the selective method; 2) employees who work in the executive organizations of Sari (29,697 people) who, according to the Cochran formula, selected 400 people by random sampling by conglomerate method. Data collection was performed using a human resources management research questionnaire with 54 questions and knowledge management with 24 questions. The CVR was calculated as 0.97.4 and 0.95.1, respectively, and was acceptable. Cronbach's alpha coefficient was also estimated above 0.7 , confirming the reliability of the instrument. In the data analysis, route tests and structural equation models were used using the Lisrel software. Based on the result, the strength of the relationship between the variables of human resource management and knowledge management was calculated at 0.48 , which showed that the correlation is strong and desirable. The t statistic (4.99) was also greater than the critical value of $\mathrm{t}$ at the $5 \%$ error level, that is, 1.96, indicating that the correlation was significant. In conclusion, it can be said that human resource management and knowledge management as two coordinating components play a determining role in the organization's competitiveness with each other, and organizations that pay attention to these important components will definitely achieve their development and excellence. desired.
\end{abstract}

Keywords: Human Resource Management, Knowledge Management, Executive Organizations, Sari, Iran.

\title{
Introduction
}

By increasing the change process in science and technology, firms and organizations become more complicated and along with this revolution, the organizations management also gets complicated. Today, managing organizations with traditional methods is not possible, since managing humans that are the main capital of organizations is not easy, and organizations' leaders, especially those in charge of human resources, needs to acquire the necessary knowledge and skills and apply them effectively (Millar \& Doherty, 2016). The research on the role of human resource specialists and managers in creating and maintain positive organizational performance has been the subject of many organizational studies over the past two decades, and it has been confirmed that human resource management is strongly related to knowledge management (Hatefi \& Rousta, 2018).

The researchers found that human resource managers can also take the management role of traditional organizations and turn it to the strategic asset of the organization. Furthermore, in recent decades, the traditional use of capital and technology as competitive forces in various industries has grown exponentially, and the transition to a knowledge-based era has been dependent on knowledge management and intellectual capital (Xian et al., 2017). McGrath (2006) believes that human resource management systems can create special economic values 
in organizations that require knowledge management in the organization to achieve these values, so it can be concluded that human resource management and knowledge management completes each other in organizations (Modiri, 2017).

In order to expand knowledge management and achieve its goals in an organization, a series of processes will be needed to make knowledge-based activities in each organization and the employees of that organization will become knowledge-based employees, which means using knowledge in doing things and processes is one of the most important priorities of every person in the organization. Therefore, human resource management works as a prerequisite for the development of knowledge management in organizations and executive organizations in our country, and a dynamic, continuous and effective educational system is needed to institutionalize knowledge in these organizations to use modern management tools, advanced techniques and technology to increase the scientific level and awareness of people in the organization due to rapid changes in today's world, which again efficient and dynamic human resource management can largely meet these expectations (Yazdanshenas et al., 2017).

The optimal quality of decisions in the organization in general and in government organizations in particular, depends on the nature of the quality of knowledge that is used, and the more up-to-date and appropriate this knowledge is, more appropriate decisions can be expected. The scope of these decisions is more important and necessary in the field of human resource management (Moghadam et al., 2017).

Many executive organizations in the country provide services to citizens relatively, that many of them are for the well-being of citizens, and some executive agencies also provide special services to some classes of society that are different according to the job and business and of individuals. However, the executive organizations are the place where the people of the organization interact as the organization's human resources and the people who referred to the organization are considered as the client, that for both sides of this interaction the knowledge management is necessary, and if either of these two groups do not benefit from knowledge management, that organization will certainly not achieve its major goals (Sepahvand et al., 2017).

With regard to the increasing changes in human societies and the changes in the organizations' stockholders, it seems that providing a single version of the human resource management model based on knowledge management for all countries and organizations cannot be accountable (Longenecker et al., 2018) and using a local model largely fills the gaps, and despite the application of knowledge-based human resource management models and models in today's organizations, the concept of its dimensions and components has not yet been properly defined, and this issue is more evident in public sectors than in other sectors (Subhanipour et al., 2018).

In Iran, the policies and programs of reforming the administrative system of the country, 
which are in accordance with the Civil Service Management Law and the five-year development plans of the country and have been developed and approved under the general policies of the Supreme Leader's Administrative System and communicated to the executive organizations are clear but the executive organizations behaves differently in implementing the rules and these policies, and in many cases the executive organization managers pay attention to the nonimplementation of these policies in their own organization (Subhanipour et al., 2018; Abolfathi et al., 2017; Sifollahi et al., 2018).

\section{Methodology}

This research is applied in terms of purpose and its method is survey research. The nature of this research is descriptive with correlation type. The statistical population includes two groups; 1) experts that are familiar with the field of human resource management and have scientific research and articles related to the research topic, availability, experience, appropriateness of the study field, Ph.D. degree, engagement in teaching at the university, which in this research, in the design section of providing a human resource management model based on the knowledge management of the executive organizations of Sari was used. In order to choose a suitable sample from the community of experts and university professors, 15 individuals were selected using non-random sampling method; 2. Employees that are working in the executive organizations of Sari (29.697 individuals, who are the staff of Sari government organizations and using Cochran's formula 400 people from 52 executive organizations were selected by random cluster sampling method. In this research, a questionnaire was used to collect the required data: the questionnaire of designing and approving model is consisted of 21 five-option questions about human resource management and 11 questions about knowledge management, that after obtaining the opinion of experts the number of human management resource items changed to 18 and knowledge management items changed to 8 . The human resource management questionnaire consists of 54 five-option questions (completely agree to completely disagree) and it is shown in Table 1.

\section{Table 1}

Characteristics of Human Resource Management Questionnaire

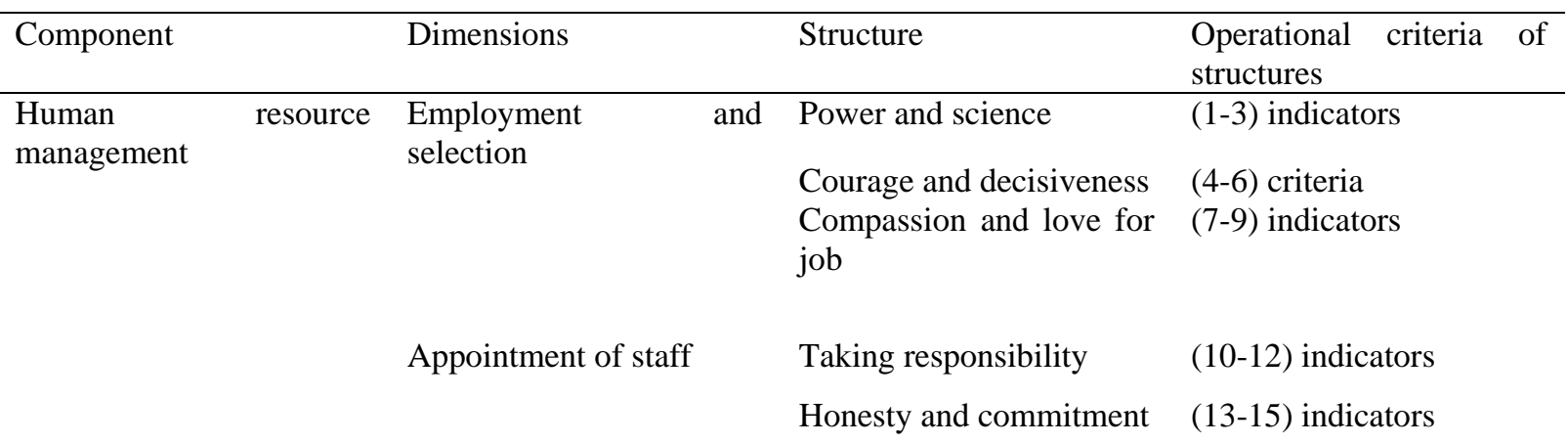




\begin{tabular}{|c|c|c|}
\hline \multirow[t]{2}{*}{$\begin{array}{l}\text { Employee development } \\
\text { and maintenance }\end{array}$} & $\begin{array}{l}\text { Develop communication } \\
\text { and professional skills } \\
\text { Empowering employees }\end{array}$ & (22-24) indicators \\
\hline & $\begin{array}{l}\text { Employability and self- } \\
\text { efficacy }\end{array}$ & (25-27) indicators \\
\hline \multirow[t]{3}{*}{$\begin{array}{l}\text { Staff education and } \\
\text { improvement }\end{array}$} & $\begin{array}{l}\text { Training employee (in- } \\
\text { service training) }\end{array}$ & (28-30) indicators \\
\hline & Organizational learning & (31-33) indicators \\
\hline & Work life quality & $(34-36)$ \\
\hline \multirow[t]{3}{*}{$\begin{array}{l}\text { Evaluating } \\
\text { performance of staff }\end{array}$} & $\begin{array}{l}\text { Observance of discipline } \\
\text { at work }\end{array}$ & (37-39) indicators \\
\hline & Collaboration at work & (40-42) indicators \\
\hline & $\begin{array}{l}\text { Improve } \\
\text { performance }\end{array}$ & (43-45) indicators \\
\hline \multirow[t]{3}{*}{$\begin{array}{l}\text { Employee } \\
\text { compensation }\end{array}$} & $\begin{array}{l}\text { Competency-based } \\
\text { payments }\end{array}$ & (46-48) indicators \\
\hline & Merit-based promotion & (49-51) indicators \\
\hline & $\begin{array}{l}\text { Payments based on the } \\
\text { customers' satisfaction }\end{array}$ & (52-54) indicators \\
\hline
\end{tabular}

The Knowledge Management Questionnaire consists of 24 five-option questions (completely agree to completely disagree) according to (Table 2).

Table 2

The Characteristics of Knowledge Management Questionnaire

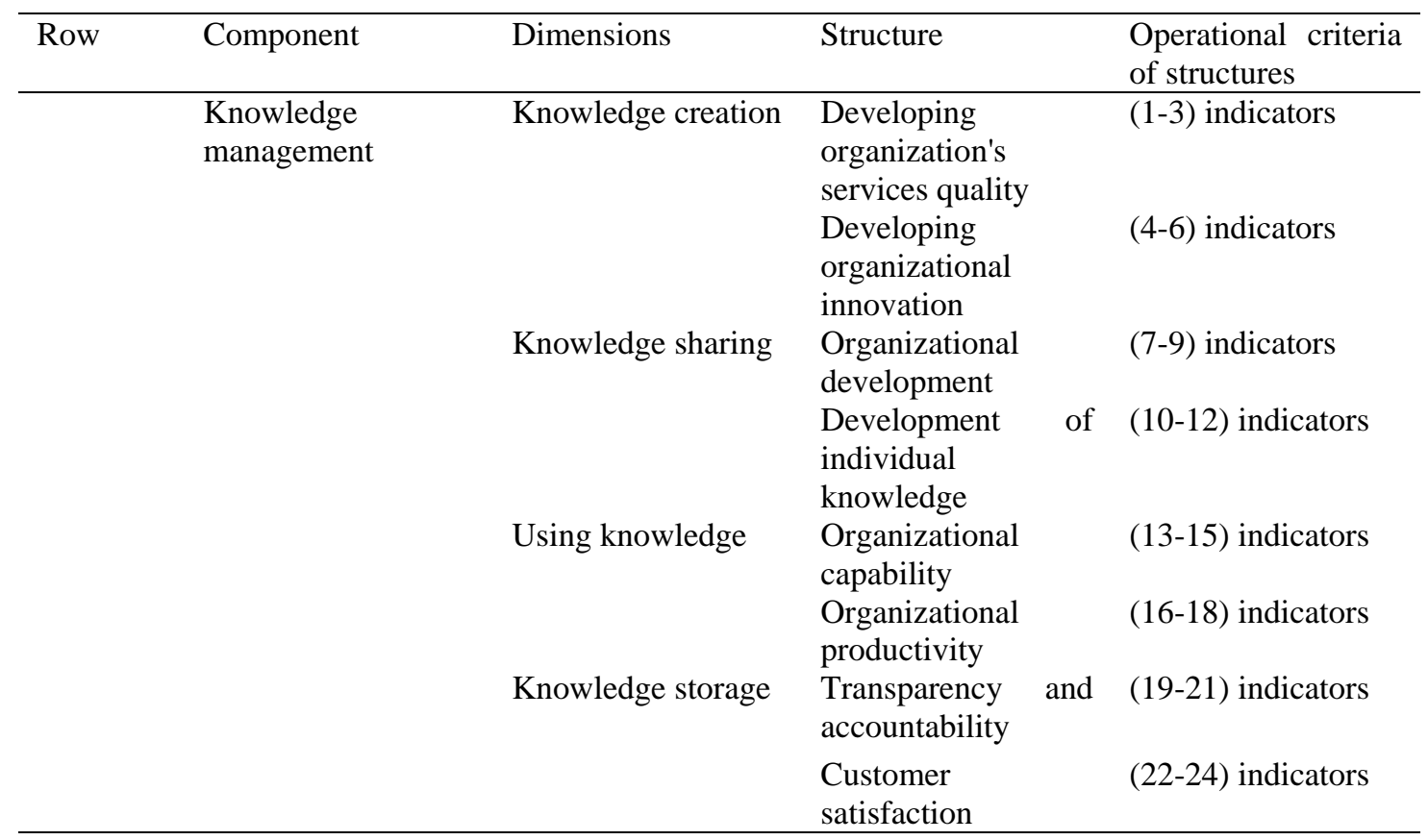

In this research, the questionnaires were confirmed by 15 experts in terms of face and conceptual validity and then to measure its content validity, content validity ratio or CVR method was used. The formula of this method is as follows: 


$$
C V R=\frac{n_{e^{-}} \frac{N}{2}}{\frac{N}{2}}
$$

Where $\mathrm{N}$ represents the total number of respondents' specialists and $\mathrm{n}_{\mathrm{e}}$ is the number of professionals who have approved the item. The CVR value can be calculated for all indicators and factors. The CVR value can fluctuate between -1 and +1 . Therefore, if the CVR is closer to one, more respondents consider the material appropriate. In this study, the validity of Human Resource Management-Based Questionnaire and Knowledge Management Questionnaire were determined by 15 experts and professors of the university, that the validity of human resource management was determined to be $97.4 \%$ and the validity of knowledge management questionnaire was $95.1 \%$. Cronbach's alpha coefficient of the variables was estimated to be above 0.7 , indicating the items internal consistency and confirmation of reliability. In order to analyze the data, path analysis and structural equation modeling were used using Lisrel software.

\section{Results}

Path analysis model in order to examine the relationship between human resource management and knowledge management

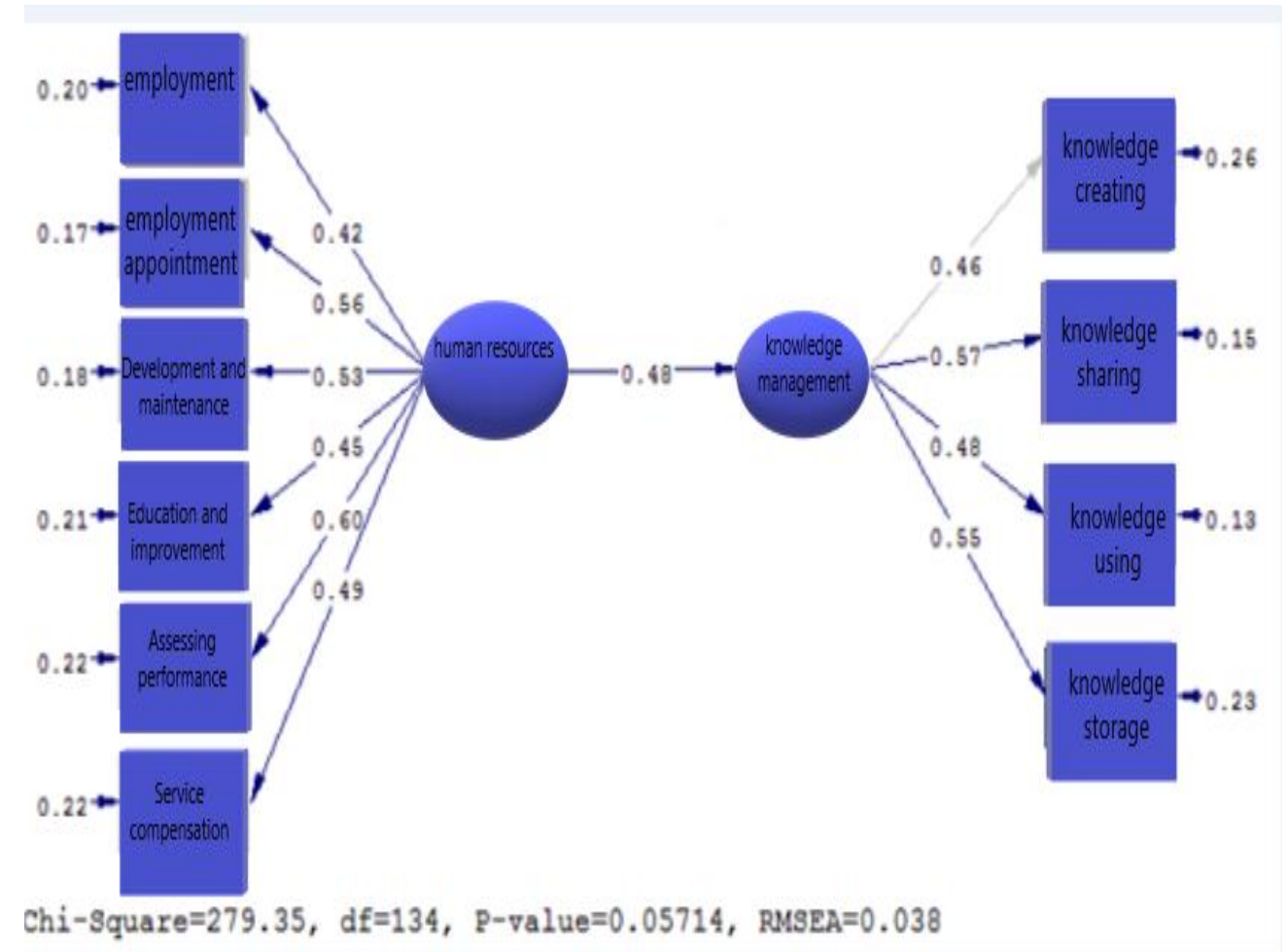

Figure 1. Results of Confirming the Final Model of the Relationship between the Main Components of the Research 


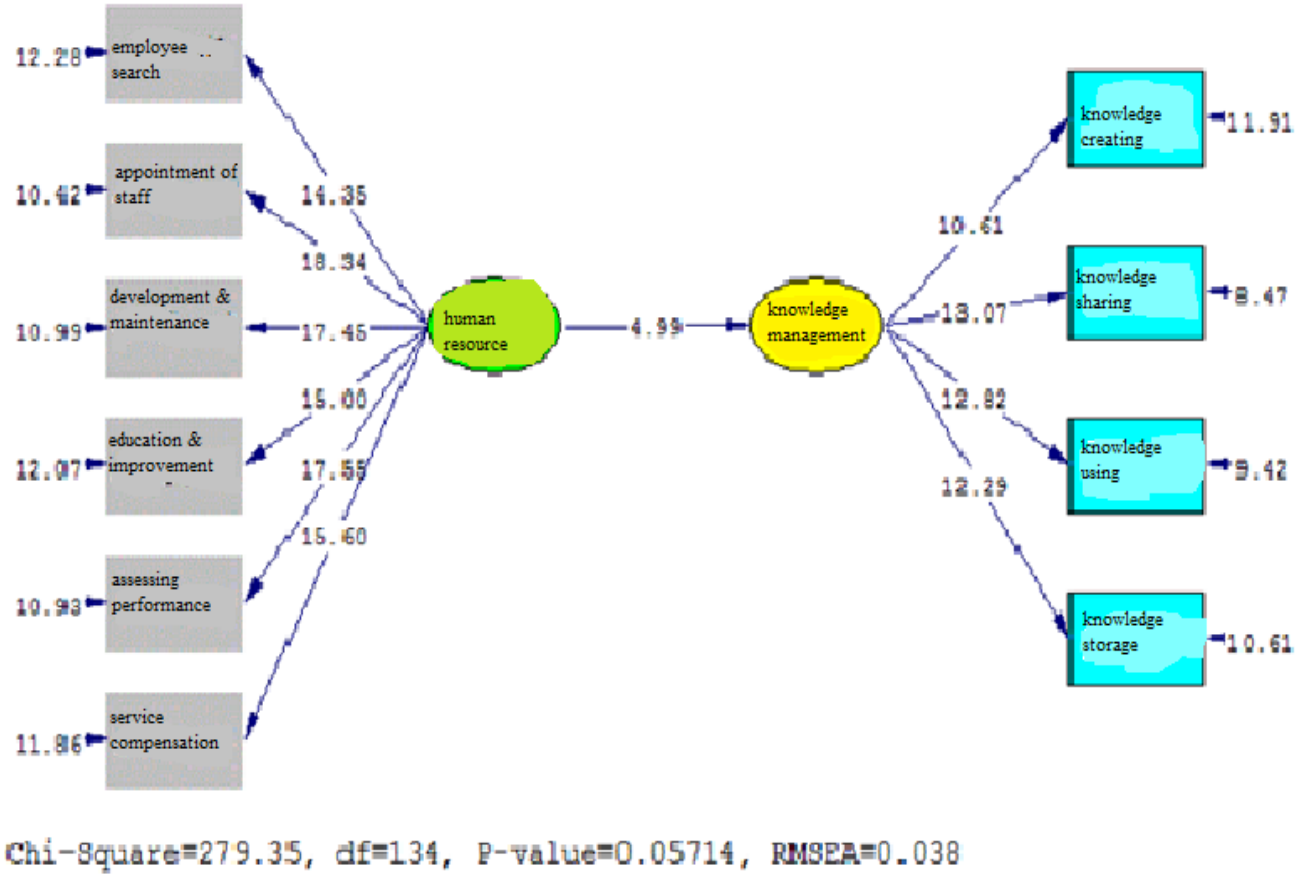

Figure 2. t-value Statistic of the Results of Confirming Final Model of the Relationship between the Main Components of the Research

Hypothesis 1: There is a significant relationship between human resource management and knowledge management in the executive organizations of Sari.

Based on (Figure 1) and (Figure 2), the power of relationship between human resource management and knowledge management variables is calculated to be 0.48 , which shows that the correlation is strong and desirable. The t-test statistic is also 4.49, which is greater than the critical value of $t$ at the error level of $5 \%$, i.e., 1.96, and shows that the observed correlation is significant.

According to (Table 3), the root mean square error of approximation (RMSEA) is 0.038, the value of normalized chi-square (CMIN / DF) is 2.085, and the value of goodness of fit index (GFI) is 0.96 which indicates the suitability of the proposed research model.

Table 3

Indicators of the Main Research Model Fit

\begin{tabular}{llc}
\hline Indicator & Reported value & $\begin{array}{l}\text { Acceptable } \\
\text { level }\end{array}$ \\
\hline $\begin{array}{l}\text { root mean square error of approximation } \\
\text { (RMESA) }\end{array}$ & 0.038 & $\leq 1$ \\
Normalized Chi-square (CMIN/DF) & 2.085 & $\leq 3$ \\
Goodness of fit index (GFI) & 0.96 & $\geq 0.9$ \\
Adjusted goodness of fit index (AGFI) & 0.97 & $\geq 0.9$ \\
Comparative fit index (CFI) & 0.98 & $\geq 0.9$ \\
Normalized fit index (NFI) & 0.97 & $\geq 0.9$ \\
Tucker-Lewis index (TLI) & 0.96 & $\geq 0.9$ \\
Incremental fit index (IFI) & 0.97 & $\geq 0.9$ \\
\hline
\end{tabular}


The Final Structural Equation Model to Examine the Relationship between Human Resource Management and Knowledge Management Components

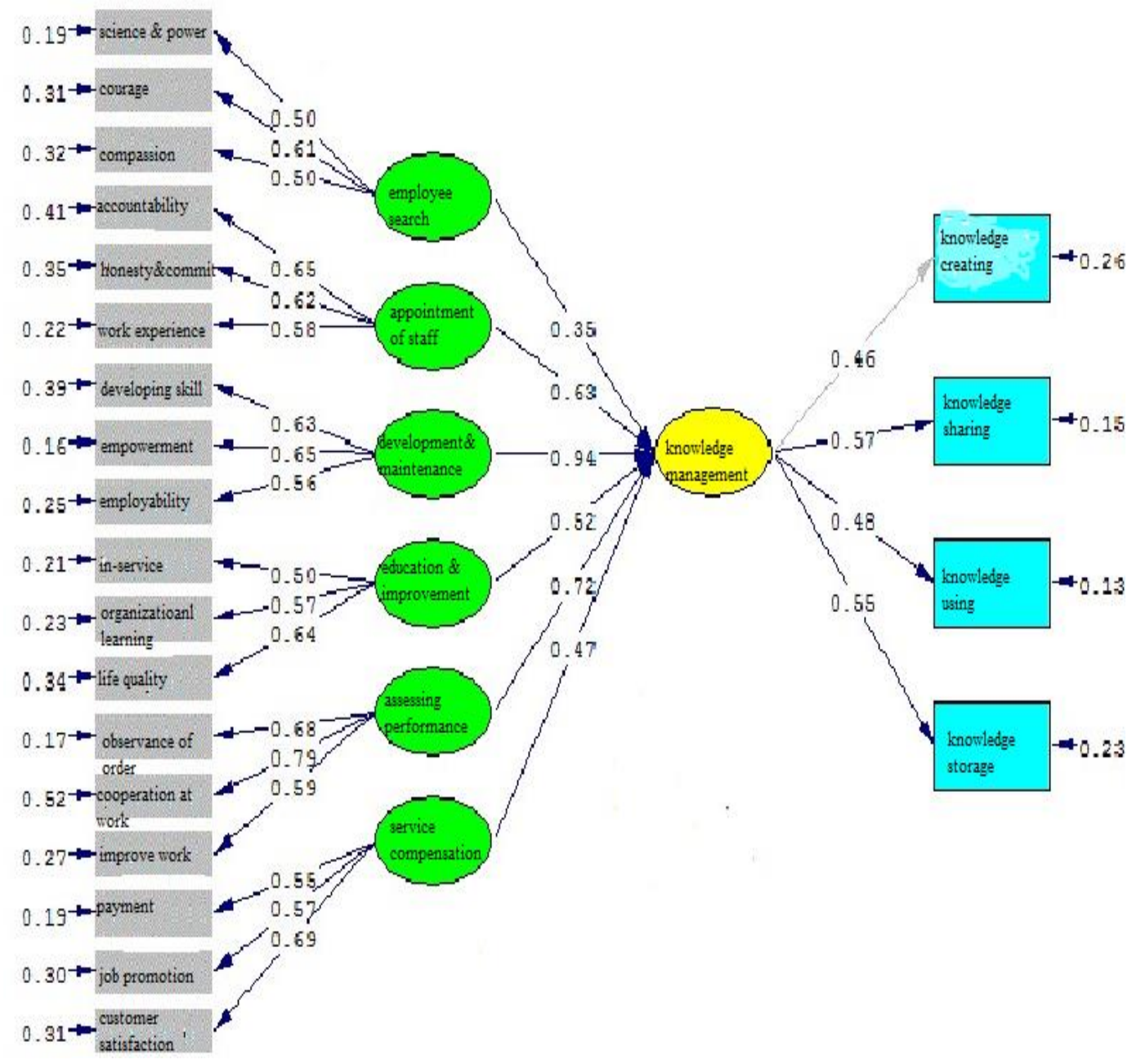

Figure 3. Results of Confirming the Final Model of the Relationship between Human Resource Management and Knowledge Management Components 


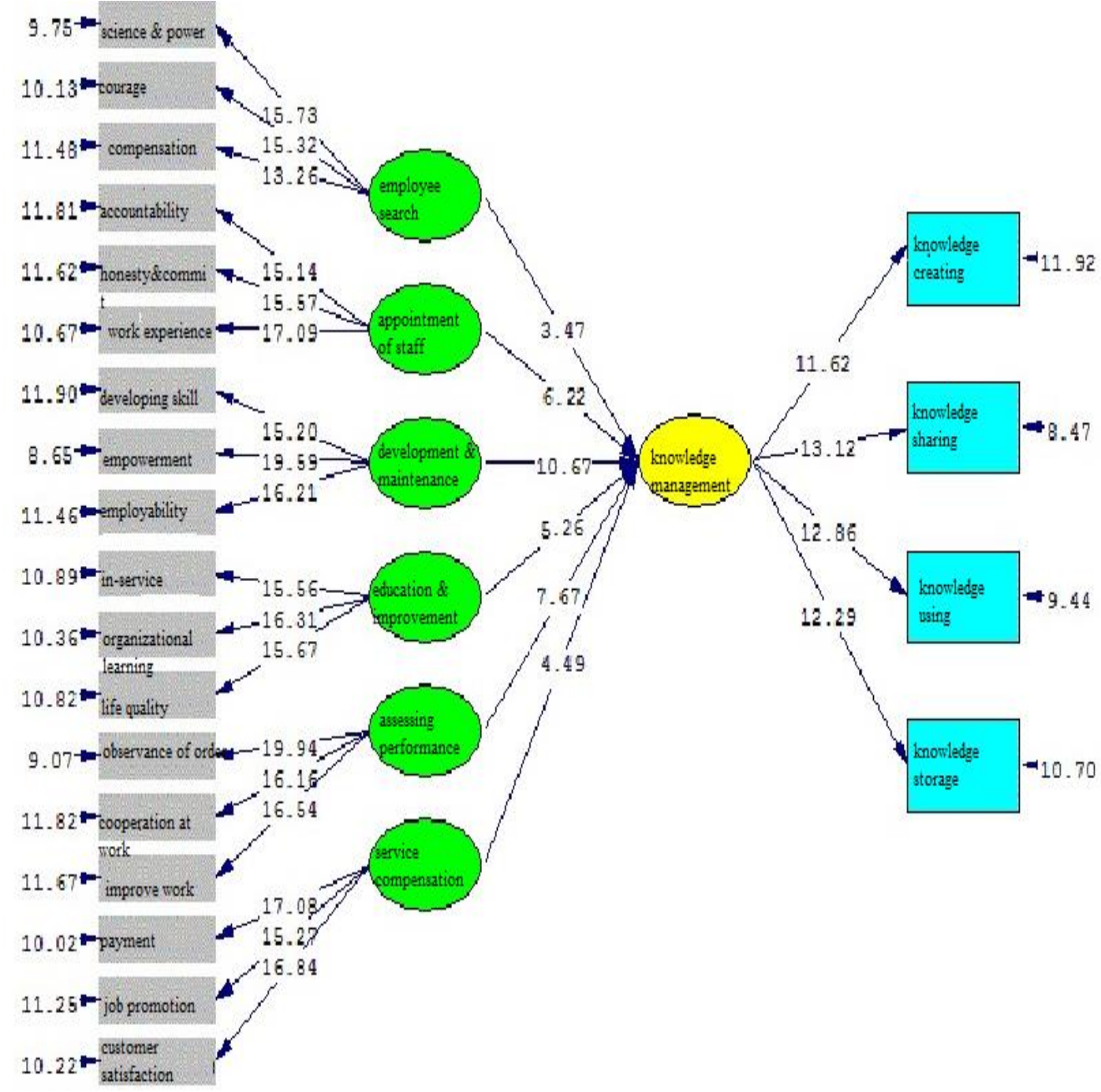

\section{Figure 4. t-value Statistics of the Results of Confirming Final Model of the Relationship between Human Resource Management and Knowledge Management Components}

Based on (Figure 3) and (Figure 4), the sub-hypotheses tests are as follows:

Sub-hypothesis 1: There is a significant relationship between recruitment and selection and knowledge management in the executive organizations of Sari.

The strength of the relationship between the variables of recruitment and selection with knowledge management has been calculated to be 0.35 , which shows that the correlation is strong and desirable. The t-test statistic is 3.47 , which is higher than the critical value of $t$ at the error level of $5 \%$, i.e., 1.96 , and shows that the observed correlation is significant.

Sub-hypothesis 2: There is a significant relationship between the appointment of employees and knowledge management in the executive organizations of Sari.

The strength of the relationship between employee appointment variables and knowledge management is calculated to be 0.63 , which shows that the correlation is strong and desirable. The t-test statistic is 6.22 , which is greater than the critical value of $\mathrm{t}$ at the error level of $5 \%$, i.e., 1.96, and shows that the observed correlation is significant.

Sub-hypothesis 3: There is a significant relationship between employee development 
and maintenance and knowledge management in the executive organizations of Sari.

The strength of the relationship between the variables of employee development and retention with knowledge management is calculated to be 0.94 , which indicates that the correlation is strong and desirable. The t-test statistic is 10.67 , which is larger than the critical value of $\mathrm{t}$ at the error level of 5\%, i.e., 1.96, and shows that the observed correlation is significant.

Sub-hypothesis 4: There is a significant relationship between staff education and improvement with knowledge management in the executive organizations of Sari.

The strength of the relationship between the variables of employee education and improvement with knowledge management is calculated to be 0.52 , which shows that the correlation is strong and desirable. The t-test statistic is 5.26, which is larger than the critical value of $\mathrm{t}$ at the error level of $5 \%$ that is 1.96 , and shows that the observed correlation is significant.

Sub-hypothesis 5: There is a significant relationship between employee performance assessment and knowledge management in Sari executive organizations.

The strength of the relationship between employee performance appraisal variables and knowledge management has been calculated to be 0.72 , which indicates a strong and desirable correlation. The t-test statistic is 7.67, which is higher than the critical value of $t$ at the error level of 5\% that is 1.96 , and shows that the observed correlation is significant.

Sub-hypothesis 6: There is a significant relationship between compensation of employees' services and knowledge management in the executive organizations of Sari.

The strength of the relationship between employee service compensation variables and knowledge management was calculated to be 0.47 , which shows that the correlation is strong and desirable. The t-test statistic is 4.49 , which is higher than the critical value of $t$ at the error level of $5 \%$ that is 1.96 , and shows that the observed correlation is significant.

According to (Table 4), the root mean square error of approximation (RMESA) is 0.018 , the normalized Chi-square value (CMIN / DF) is equal to 1.891, and the value of goodness of fit index (GFI) is 0.96 which shows the suitability of the proposed research model. 


\section{Table 4}

Fit Indicators of the Main Research Model

\begin{tabular}{llc}
\hline Indicator & $\begin{array}{l}\text { Reported } \\
\text { value }\end{array}$ & $\begin{array}{l}\text { Acceptable } \\
\text { level }\end{array}$ \\
\hline $\begin{array}{l}\text { Root mean square error of approximation } \\
\text { (RMESA) }\end{array}$ & 0.018 & $\leq 1$ \\
Normalized Chi-square (CMIN/DF) & 1.891 & $\leq 3$ \\
Goodness of fit index (GFI) & 0.96 & $\geq 0.9$ \\
Adjusted goodness of fit index (AGFI) & 0.96 & $\geq 0.9$ \\
Comparative fit index (CFI) & 0.99 & $\geq 0.9$ \\
Normalized fit index (NFI) & 0.96 & $\geq 0.9$ \\
Tucker-Lewis index (TLI) & 0.96 & $\geq 0.9$ \\
Incremental fit index (IFI) & 0.95 & $\geq 0.9$ \\
\hline
\end{tabular}

\section{Discussion}

Based on the correlation results and strength of the relationship between the two variables of human resource management and knowledge management was desirable and these results are consistent with the findings of Rajabi et al. (2016) and Hashemi et al. (2016). In explaining this finding, it can be said that manpower is the main factor in creating a competitive advantage for the organization. Human resource management is a way to make decisions about the organization's goals and plans, and in this regard, it considers the needs of human capital and also the development of process capabilities and plays a key role in managing organizational knowledge, and as a vital activating element in organizations is considered to create value and maintain a sustainable competitive advantage in today's complicated and changing environment. Organizations that are more innovative in developing human resource management and, of course, knowledge management are more responsive to the environment and will be more successful than other competitors and organizations. Therefore, it can be noted that human resource management and knowledge management as two coordinator components play a decisive role in the competitiveness of the organization and organizations that notice to these subjects, i.e., human resources and knowledge management, will certainly achieve their desired development and excellence.

Based on the correlation and strength results, the relationship between the two variables of recruitment and selection with knowledge management is desirable, and these results are in consistent with the findings of Sons (2016) and Kianto et al. (2017). In explaining this finding, it can be said that internal promotion policy is one of the main sources of employment and tools such as management skills inventory, replacement table and succession plan and attention to knowledge management are the tools that organizational officials can make the necessary appointments by referring to them when needed. However, this policy should not prioritize the existing employees for the vacant position, rather when there is no suitable workforce for the inside job; it is necessary to choose a workforce from outside of the organization. It can also be 
concluded that the inventory list of skills within the organization should be considered first, but it should always be noted that this type of policy with all the advantages has disadvantages that should be also considered and in some cases the use of promotion policy prevents the progress and development of the organization.

Based on the correlation and strength results, the relationship between the two variables of employee appointment and knowledge management is desirable, and these results are in consistent with the findings of Jacobs (2017) and Sang (2016). Therefore, it can be said that promotion and appointment of the most competent manpower accurately and purposefully is one of the main factors that leads to the success of an organization. Competent human resourcer can make the best use of available resources with its power of thought. Making decision about assigning and promoting employees with regard to the issue of competency is considered as one other up-to-date issues in organizations. One of the biggest concerns of wise managers is choosing and appointing the right people in the right place with their organizational skills. The experienced manager considers the organization as a chessboard, the first logical step of which is to arrange the pieces correctly. He knows that each of the chess pieces has a specific and different function and some of them are not a good substitute for each other. Therefore, experienced managers cleverly adapt the position of individuals to their experience and knowledge and consciously consider that failure to comply with this issue can have irreparable consequences. Based on this, it can be said that in appointing employees, paying attention to knowledge management can have a significant impact on the success of the organization and as a result, the effective performance of the organization's employees.

Based on the correlation and strength results, the relationship between the two variables of employee development and maintenance with knowledge management is desirable, and these results are consistent with the findings of Matošková \& Směšná (2018) and Yong (2019). In explaining this finding, it can be said that human capital, which is considered to be one of the most effective tools for organizational empowerment, is done simultaneously by the administrative affairs manager. Of course, in many cases, not only administration goes well, but also things related to organizational resources are not productive, and most employees are unhappy with the imposed unpleasant consequences. In such a collection, employees are constantly complaining about errors in attendance lists, miscalculations of overtime hours, vacations and administrative missions, and the ongoing irregularities they face due to lack of accountability and unprofessional treatment of those concerned. In these cases, the administrative officer ignores his / her duties and responsibilities due to lack of control over the affairs and leaves the responsibility and consequences of matters that are solely the responsibility of the administrative and office staff to other employees (Huang, 2017). Therefore, in order to develop and keep the organization's human resources and improve its programs, knowledge management in the organization must be strengthened in order to prevent 


\section{Conclusion}

Based on the results, it was found that the correlation and strength of the relationship between the two variables of employee service compensation with knowledge management is desirable and these results are in consistent with the findings of Soo et al. (2016) and Budiarti, (2017). In explaining this finding, we can say that hiring and retaining qualified employees is a common goal shared by many employers. To some extent, the availability and cost of qualified applicants for open positions is determined by market factors and are beyond the control of the employer. While an employer can set compensation to compensate for new hires and propagate it for salary range advertising, and it will be done in the context of other employers seeking employment in the same applicant pool. Spirituality and job satisfaction are under the effect of compensation. There is often a balance between the monetary value that the employer wants to pay and the value that is felt as a worker. Organizational policies of compensating financial services are effective. Some Organizations set policies in a way that are leading in terms of payment in the community. Some try to have a moderate position in the labor market, and some may have a follow-up policy. Leading organizations professionals in terms of payment expect to reduce the costs of a manufacturing unit by labor costs because they have concluded that they are able to attract people with high expertise and analysis. So knowledge management is one of the most important principles of employee service compensation.

\section{References}

Abolfathi-Jamshid R., Zamahni M. \& Estiri M. (2017), Designing and Explaining the Strategic Human Resource Management Model of High-performance Work Systems (Case study: knowledge-based companies). Journal of Management, Economics and Accounting, 6(4): 25-36.

Budiarti I. (2017), Knowledge Management and Intellectual Capital - A Theoretical Perspective of Human Resource Strategies and Practices, European Journal of Economics and Business Studies, 8(1): 148-155.

Gholamreza Modiri M. (2017), Designing a Process Model to Achieves High-Commitment Human Resource Management in Government Organizations, Journal of Development and Transformation Management, 33(2): 31-43.

Hashemi H., Akradi E. \& Yousefi M. (2016), Investigating the Effect of Human Resource Management on Knowledge Management and Organizational Innovation, Journal of Epistemological Studies, 2(8): 11-19.

Hatefi M. \& Rousta A. (2018), Investigating the Relationship between Knowledge Management 
and Organizational Performance: The Mediating Role of Management Styles. Journal of Law Enforcement and Security, 12(4): 231-252.

Huang T. (2017), Investigating the Relationship between Human Resource Management and Knowledge Management and Organizational Development in Philippine Service Companies. European Journal of Information Systems, 13(7): 321-352.

Jacobs, R. L. (2017), Knowledge Work and Human Resource Development, Human Resource Development Review, gain exposure, 16(2): 176-202.

Kianto D., Chow C. \& Wu A. (2017), conducted a study entitled Knowledge-Based Human Resource Management Methods and Its Impact on Organizational Performance. Journal of Management Studies, 46(1): 65-92.

Longenecker H., Clinton O. \& Neubert M. (2018). Barriers and Gateways to Management Cooperation and Teamwork. Business Horizons, 7(6): 278-295.

Martin-Sons, M. (2016), Human resource management applications of knowledge-based systems, International Journal of Information Management, 17(1): 35-53.

Matošková J. \& Směšná P. (2018), Human resource management practices stimulating knowledge sharing, Management \& Marketing, Challenges for the Knowledge Society, 12(4): 1-11.

Millar P. \& Doherty A. (2016), Capacity building in nonprofit sport organizations: Development of a process model, Sport Management Review, 17(1): 114-126.

Mohammadi-Moghadam Y., Shabani A., Mansouri-Mohammadabadi S. \& Mohammadi K. (2017), Investigating the Effect of Knowledge Management Capability on the New Product Development Process. Journal of Industrial Development and Technology, $16(3): 23-32$.

Rajabi M., Hassani M. \& Mohajeran B. (2016), Investigating the Role of Human Resource Development Activities on Employee Innovation by Testing the Mediating Role of Knowledge Management and Organizational Learning. Journal of Innovation and Creativity in the Humanities, 6(3): 151-178.

Sang L. (2016), Investigating the Impact of the Role of Strategic HR Management on Perceived Organizational Support and Improving Organizational Performance in Hungarian Manufacturing Industries. International Journal of Project Management, 18(12): 171188.

Sepahvand, R., Saedi A. \& Momeni-Mofrad M. (2017). Designing a Green Human Resource Management Model in Sports Organizations using an Interpretive Structural Modeling Approach. Quarterly Journal of Human Resource Management in Sports, 6(1): 17-34.

Sifollahi N., Hazeri H. \& Asoudeh A. (2018), Investigating the Effect of Knowledge Management and Technological Innovation on Creating Competitive Advantage (Research sample: Pars Khazar and Pars Shahab manufacturing companies). Journal of 
Organizational Knowledge Strategic Studies, 2(5), pp. 13-52.

Soo, C., Amy, W., Stephen, T. \& John, C. (2016), Intellectual Capital-Enhancing HR, Absorptive Capacity, and Innovation, Human Resource Management, 56(3): 431-454.

Subhanipour M., Zarei-Matin H., Alvani M. \& Jandaghi G. (2018), Designing an Effective Human Resource Management Model based on Participatory Organizational Culture in the Public Sector of Iran, Journal of Public Management Research, 12(43): 59-83.

Xian H., Atkinson C. \& Meng-Lewis Y. (2017), Guanxi and high-performance work systems in China: evidence from a state-owned enterprise. The International Journal of Human Resource Management, 8(5): 69-87.

Yazdanshenas M., Hadi Peykani M. \& Gholizadeh A. (2017), Designing a Human Resource Development Model based on the Requirements of the Navy of the Army of the Islamic Republic of Iran. Quarterly Journal of Marine Science Education, 5(2): 109-130.

Yong, M. (2019), Investigating the Relationship between Green Knowledge Capital and Green Human Resource Management. Management Decision, 46(5): 158-169. 